University of Nebraska - Lincoln

DigitalCommons@University of Nebraska - Lincoln

Agronomy \& Horticulture - Faculty Publications

Agronomy and Horticulture Department

January 1990

\title{
Yield and Quality Response of Subirrigated Meadow Vegetation to Nitrogen, Phosphorus and Sulfur Fertilizer
}

\author{
James T. Nichols \\ University of Nebraska-Lincoln \\ Patrick E. Reece \\ University of Nebraska-Lincoln, preece1@unl.edu \\ Gary W. Hergert \\ University of Nebraska-Lincoln, ghergert1@unl.edu \\ Lowell E. Moser \\ University of Nebraska-Lincoln, Imoser1@unl.edu
}

Follow this and additional works at: https://digitalcommons.unl.edu/agronomyfacpub

Part of the Plant Sciences Commons

Nichols, James T.; Reece, Patrick E.; Hergert, Gary W.; and Moser, Lowell E., "Yield and Quality Response of Subirrigated Meadow Vegetation to Nitrogen, Phosphorus and Sulfur Fertilizer" (1990). Agronomy \& Horticulture -- Faculty Publications. 78.

https://digitalcommons.unl.edu/agronomyfacpub/78

This Article is brought to you for free and open access by the Agronomy and Horticulture Department at DigitalCommons@University of Nebraska - Lincoln. It has been accepted for inclusion in Agronomy \& Horticulture -Faculty Publications by an authorized administrator of DigitalCommons@University of Nebraska - Lincoln. 


\title{
Yield and Quality Response of Subirrigated Meadow Vegetation to Nitrogen, Phosphorus and Sulfur Fertilizer
}

\author{
James T. Nichols, ${ }^{*}$ Patrick E. Reece, Gary W. Hergert, and Lowell E. Moser
}

\begin{abstract}
Production practices that increase hay yields are important for beef cattle producers in the Nebraska Sandhills. This study evaluated the responses of subirrigated meadow vegetation to fertilization with $N, P$, and $S$ over a 4-yr period. A factorial array of four levels of $N\left(0,45,90\right.$ and $\left.135 \mathrm{~kg} \mathrm{ha}^{-1}\right)$, two levels of $P\left(0\right.$ and $\left.20 \mathrm{~kg} \mathrm{ha}^{-1}\right)$ and two levels of $S\left(0\right.$ and $\left.22 \mathrm{~kg} \mathrm{ha}^{-1}\right)$ were applied each year to the same plots, arranged in a randomized complete block design. Average dry matter yields were increased by $\mathbf{N}, \mathbf{P}$, and $\mathbf{S}$. There were no fertilizer interaction effects. Yields increased quadratically as $\mathbf{N}$ levels increased. For each $45 \mathrm{~kg}$ increment of $\mathrm{N}$ applied from 0 to $135 \mathrm{~kg} \mathrm{ha}^{-1}$, dry matter yield (pooled over $P$ and $S$ ) increased 1002 , 703 , and $402 \mathrm{~kg} \mathrm{ha}^{-1}$, respectively. Main effects of $P$ and $S$ increased dry matter yields by 4662 and $577 \mathrm{~kg} \mathrm{ha}^{-1}$, respectively. Nitrogen uptake was increased linearly by fertilization with $N, P$, and $S$. Forage $\mathbf{N}$ use efficiency decreased as $\mathbf{N}$ fertilizer rates increased. Crude protein (CP) declined quadratically as $\mathbf{N}$ rates increased, but the maximum change was less than $10 \mathrm{~g} \mathrm{~kg}^{-1}$. In vitro dry matter digestibility (IVDMD) declined linearly as $\mathrm{N}$ rates increased. Sulfur and $P$ did not affect either $C P$ or IVDMD. Yield responses were sufficient to justify the use of $N, P$, and $S$ to increase subirrigated meadow production. Loss of forage quality (CP and IVDMD) was not sufficient to nullify this conclusion.
\end{abstract}

J.T. Nichols and G.W. Hergert, Dep. of Agronomy, Rt. 4, Box 46A, West Central Res. Ext. Cent., North Platte, NE 69101; P.E. Reece, Dep. of Agronomy, 4502 Ave. I, Panhandle Res. Ext. Cent., Scottsbluff, NE 69361; and L.E. Moser, Dep. of Agronomy, 352 Keim Hall, Univ. Nebraska, Lincoln, NE 68583. Contribution of the Neb. Agric. Res. Div., Lincoln, NE, as Paper no. 8758. Received 13 Oct. 1988. * Corresponding author.

Published in Agron. J. 54:47-52 (1990).
- AY from subirrigated meadows is an essential for1 age resource that supports livestock wintering programs within the 4.8-million ha region of the $\mathrm{Ne}$ braska Sandhills. Hay yield and quality are often below site potential. Because of subirrigation, soil water is seldom a factor limiting production. This enhances the potential for increased hay production through improved management practices. A major constraint to high hay yields is low soil fertility. Several studies in subirrigated meadow environments have shown a positive yield response to fertilization (Brouse and Burzlaff, 1968; Daigger and Moline, 1977; Ehlers et al., 1952; McConnell and Waller, 1986; Rehm et al., 1973). It is well accepted that the application of fertilizer can alleviate soil nutrient deficiencies and increase forage yields. However, the magnitude of this response merits further evaluation as a management practice on subirrigated meadows. In addition, the effect of fertilization on forage CP content and IVDMD has not been adequately documented for subirrigated sites and should be considered along with yield response. This study was conducted to quantify the yield, $\mathrm{N}$ uptake, $\mathrm{N}$ use efficiency and quality responses of subirrigated meadow vegetation to fertilization with $\mathrm{N}, \mathrm{P}$, and $\mathrm{S}$.

\section{MATERIALS AND METHODS}

The study site was located on a subirrigated meadow at the University of Nebraska, Gudmundsen Sandhills Labo- 
Table 1. Initial soil characteristics of the study site. Gudmundsen Sandhills Lab., Whitman, NE.

\begin{tabular}{ccccccc}
\hline Depth & $\mathrm{pH}$ & $\begin{array}{c}\text { Organic } \\
\text { matter }\end{array}$ & $\mathrm{P}($ Bray-1) & $\mathrm{K}$ & $\mathrm{NO}_{3}-\mathrm{N}$ & $\mathrm{SO}_{4}-\mathrm{S}$ \\
\hline $\mathrm{cm}$ & & $\mathrm{g} \mathrm{kg}^{-1}$ & \multicolumn{6}{c}{$\mathrm{mg} \mathrm{kg}^{-1}$} \\
\cline { 3 - 7 } & 7.6 & 111 & 5 & 120 & 2.1 & 16 \\
$15-30$ & 7.7 & 41 & 3 & 102 & 1.3 & 4 \\
$30-45$ & 7.8 & 34 & 4 & 107 & 1.0 & 3 \\
\hline
\end{tabular}

ratory near Whitman, Neb. Soils at the study site were classified as Gannett-Loup fine sandy loams (coarse-loamy, mixed, mesic Typic Haplaquolls) which were derived from eolian sand parent material. Selected soil properties at the study site are presented in Table 1. Even though the $\mathrm{pH}$ was high, this site was not calcareous, thus the Bray P test was considered a valid indicator of $P$ availability.

The dominant vegetation consisted of smooth bromegrass (Bromus inermis Leyss.), redtop (Agrostis stolonifera L.), timothy (Phleum pratense L.), slender wheatgrass [Agropyron trachycaulum (Link) Malte], quackgrass $[A$. repens $(\mathbf{L})$. Beauv.], Kentucky bluegrass (Poa pratensis L.), prairie cordgrass (Spartina pectinata Link) and several species of sedges (Carex spp. L.), rushes (Juncus spp. L.) and spikerushes (Eleocharis spp. R.). Less abundant grass species were big bluestem (Andropogon gerardii Vitman), Indiangrass [Sorghastrum nutans (L.) Nash], and switchgrass (Panicum virgatum L.). Legumes and other forbs were minor components of the vegetation. Nomenclature of plants follows Great Plains Flora Association (1986).

Soil water was not a limiting factor during the study because of natural subirrigation. Soils were water saturated at the surface when growth was initiated in the spring and remained wet within the rooting depth of the vegetation throughout the growing season.

Four levels of $\mathrm{N}\left(0,45,90\right.$, and $\left.135 \mathrm{~kg} \mathrm{ha}^{-1}\right)$, two levels of $P\left(0\right.$ and $\left.20 \mathrm{~kg} \mathrm{ha}^{-1}\right)$ and two levels of $S\left(0\right.$ and $\left.22 \mathrm{~kg} \mathrm{ha}^{-1}\right)$ were broadcast on the same plots ( 3 by $12 \mathrm{~m}$ ) each year in April prior to the initiation of new growth. Fertilizer sources were ammonium nitrate $(34-0-\mathrm{O})$, triple super phosphate $(0-$ 45-0) and gypsum $\left(\mathrm{CaSO}_{4} \cdot 2 \mathrm{H}_{2} \mathrm{O}\right)$. Field plot design was a factorial arrangement of treatments replicated four times in a randomized complete block. Blocking criteria were based on degree of soil wetness due to subirrigation. Standing crop weight estimates from each treatment were obtained by harvesting an area $(0.9$ by $10 \mathrm{~m})$ at a $5-\mathrm{cm}$ cutting height on 21 July, 26 July, 18 July, and 25 June for the four consecutive years (1982-1985). These cutting dates corresponded to the time of normal haying operations which were determined primarily by degree of wetness at the soil surface. The dominant species were at anthesis at time of harvest. Representative subsamples were obtained from the harvested material, oven dried at $60^{\circ} \mathrm{C}$ to a constant weight, and used to convert yield values to a dry-matter basis. These subsamples were analyzed for $\mathrm{N}$ content by the Kjeldahl method (Association of Official Analytical Chemists, 1975) and IVDMD by procedures outlined by Martin and Barnes (1980). Crude protein was estimated from Kjeldahl-N $(6.25 \times \mathrm{N})$. Nitrogen uptake values were calculated as a product of yield and forage- $\mathrm{N}$ content.

Forage $\mathrm{N}$ use efficiency is often expressed as the increased kilogram of forage produced per kilogram of $\mathrm{N}$ fertilizer added; it may also be called marginal $\mathrm{N}$ use efficiency (Gomm, 1979; Ludwick, 1979; Taylor et al., 1985). Similarly, in this study, forage $\mathrm{N}$ use efficiency was calculated by dividing the difference in forage yield between fertilized and nonfertilized treatments by the amount of applied $\mathrm{N}$.

Normality of data was confirmed within each year by testing normality of residuals using PROC UNIVARIATE (SAS Institute, Inc., 1985). This was followed by analysis of var-
Table 2. Probability $(P>F)$ for block (B), year (YR), N, P, and $S$ effects on dry matter yield, $N$ uptake, $C P$ concentration and IVDMD on a fertilized subirrigated meadow at the Gudmundsen Sandhills Lab., Whitman, NE, 1982 to 1985.

\begin{tabular}{|c|c|c|c|c|c|}
\hline Source & $d f$ & Dry matter & $\mathbf{N}$ uptake & $\mathbf{C P}$ & IVDMD \\
\hline & & & $P$ & & \\
\hline B & 3 & 0.001 & 0.019 & 0.001 & 0.333 \\
\hline YR & 3 & 0.001 & 0.001 & 0.110 & 0.001 \\
\hline $\mathrm{YR} \times \mathrm{N}$ & 9 & 0.001 & 0.001 & 0.001 & 0.061 \\
\hline $\mathbf{Y R} \times \mathbf{P}$ & 3 & 0.151 & 0.119 & 0.254 & 0.826 \\
\hline $\mathbf{Y R} \times \mathbf{N} \times \mathbf{P}$ & 9 & 0.217 & 0.277 & 0.872 & 0.145 \\
\hline $\mathbf{Y R} \times \mathbf{S}$ & 3 & 0.625 & 0.683 & 0.611 & 0.853 \\
\hline $\mathbf{Y R} \times \mathbf{N} \times \mathbf{S}$ & 9 & 0.685 & 0.846 & 0.875 & 0.468 \\
\hline $\mathbf{Y R} \times \mathbf{P} \times \mathbf{S}$ & 3 & 0.122 & 0.483 & 0.741 & 0.535 \\
\hline $\mathbf{Y R} \times \mathbf{N} \times \mathbf{P} \times \mathbf{S}$ & 9 & 0.958 & 0.716 & 0.591 & 0.374 \\
\hline $\mathbf{N}$ & 3 & 0.001 & 0.001 & 0.001 & 0.003 \\
\hline $\mathbf{N}$ linear & 1 & 0.001 & 0.001 & 0.001 & 0.001 \\
\hline $\mathrm{N}$ quadratic & 1 & 0.001 & 0.629 & 0.001 & 0.131 \\
\hline N cubic & 1 & 0.211 & 0.709 & 0.368 & 0.977 \\
\hline $\mathbf{P}$ & 1 & 0.001 & 0.001 & 0.385 & 0.674 \\
\hline $\mathbf{N} \times \mathbf{P}$ & 3 & 0.285 & 0.411 & 0.781 & 0.512 \\
\hline $\mathbf{S}$ & 1 & 0.001 & 0.001 & 0.748 & 0.059 \\
\hline $\mathbf{N} \times \mathbf{S}$ & 3 & 0.327 & 0.588 & 0.369 & 0.203 \\
\hline $\mathbf{P} \times \mathbf{S}$ & 1 & 0.541 & 0.876 & 0.063 & 0.353 \\
\hline $\mathbf{N} \times \mathbf{P} \times \mathbf{S}$ & 3 & 0.166 & & 0.334 & \\
\hline Error mean square & & 516869 & 146 & 0.59 & 6.58 \\
\hline $\mathrm{CV}$ & & $10.5 \%$ & $13.2 \%$ & $9.2 \%$ & $4.8 \%$ \\
\hline
\end{tabular}

iance as a split plot in time over all years for dry matter yield, $\mathrm{N}$ uptake, $\mathrm{CP}$, and IVDMD (Table 2). The level of significance selected for treatment effects was $P \leq 0.05$. The YR $\times \mathrm{N}$ effects were small, but statistically significant. A Bartlett's test of homogeneity of variance was performed on all parameters among years (Snedecor and Cochran, 1968). This test showed homogeneity for all parameters, so years were pooled. Single degree of freedom contrasts were used to separate $\mathrm{N}$ main effects. Dry matter yield, $\mathrm{N}$ uptake, $\mathrm{CP}$, and IVDMD models were examined to determine the most appropriate fit for response patterns.

A polynomial model was used to describe $\mathrm{N}$ response and was of the form

$$
\hat{Y}=b+c_{1} \mathbf{N}+c_{2} \mathrm{~N}^{2}
$$

Where $\hat{Y}=$ dependent variables,

$$
\begin{aligned}
& b=Y \text { intercept, } \\
& c_{1}=\text { coefficient of the } \mathrm{N} \text { linear term, and } \\
& c_{2}=\text { coefficient of the } \mathrm{N} \text { quadratic term. }
\end{aligned}
$$

Because main effects of $P$ and $S$ were additive, regression models for $\mathrm{N}, \mathrm{N}+\mathrm{P}, \mathrm{N}+\mathrm{S}$, and $\mathrm{N}+\mathrm{P}+\mathrm{S}$ were calculated.

\section{RESULTS AND DISCUSSION}

\section{Dry Matter Yields}

Mean dry matter yields showed a significant response when fertilized with individual or combined applications of $N, P$, or $S$ each year (Table 2). Dry matter yield responses to $\mathrm{N}, \mathrm{P}$, and $\mathrm{S}$ were additive. There were no significant nutrient interaction effects on yield for any of the fertilizer combinations (Table 2).

The yield response to increased levels of $\mathrm{N}$ (pooled over $\mathrm{P}$ and $\mathrm{S}$ ) was quadratic (Fig. 1). The regression equation showed forage yields increased 1002, 703, and $402 \mathrm{~kg} \mathrm{ha}^{-1}$, respectively, for each $45 \mathrm{~kg}$ of $\mathrm{N}$ applied from 0 to $135 \mathrm{~kg} \mathrm{ha}^{-1}$. The main effect of $P$ was significant and showed an increase of $662 \mathrm{~kg} \mathrm{ha}^{-1}$ (Table 3). The main effect response to $22 \mathrm{~kg} \mathrm{ha}^{-1} \mathrm{~S}$ was $577 \mathrm{~kg} \mathrm{ha}^{-1}$. The highest production resulted from the combined application of $\mathrm{N}, \mathrm{P}$, and $\mathrm{S}$ at 135, 20, 
Table 3. Average annual dry matter yield, $N$ uptake, $C P$ concentration and IVDMD from a subirrigated meadow fertilized with $\mathbf{N}$, $P$, and $S$ at the Gudmundsen Sandhills Lab., Whitman, NE, 1982 to 1985 .

\begin{tabular}{|c|c|c|c|c|c|c|}
\hline \multicolumn{3}{|c|}{ Fertilizer } & \multirow{2}{*}{$\begin{array}{c}\text { Dry matter } \\
\text { yield }\end{array}$} & \multirow[b]{2}{*}{ N uptake } & \multirow[b]{2}{*}{$\mathrm{CP}$} & \multirow[b]{2}{*}{ IVDMD } \\
\hline $\mathbf{N}$ & $\mathbf{P}$ & $\mathbf{S}$ & & & & \\
\hline \multicolumn{3}{|c|}{ 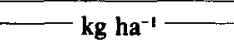 } & \multicolumn{2}{|c|}{$-\mathrm{kg} \mathrm{ha}^{-1}$} & \multicolumn{2}{|c|}{$\mathbf{g ~ k g}^{-1}-$} \\
\hline $\mathbf{0}$ & 0 & 0 & $4962 a^{*}$ & $72 a$ & $90.6 \mathrm{a}$ & $561 \mathrm{a}$ \\
\hline 45 & 0 & 0 & $6012 b$ & $78 \mathrm{a}$ & $81.7 b$ & $535 b$ \\
\hline 90 & 0 & 0 & $6794 c$ & $89 b$ & $81.7 b$ & $534 b$ \\
\hline 135 & 0 & 0 & $7072 c$ & $92 b$ & $81.4 \mathrm{~b}$ & $532 b$ \\
\hline 0 & 20 & 0 & 5544d & $79 \mathrm{c}$ & $88.2 c$ & $560 \mathrm{c}$ \\
\hline 45 & 20 & 0 & $7330 \mathrm{e}$ & $94 d$ & $80.8 d$ & $549 \mathrm{~cd}$ \\
\hline 90 & 20 & 0 & $6978 \mathrm{e}$ & $90 d$ & $80.5 d$ & 538ed \\
\hline 135 & 20 & 0 & $7987 f$ & $106 \mathrm{e}$ & $82.6 \mathrm{~d}$ & $525 \mathrm{e}$ \\
\hline 0 & 0 & 22 & $5977 \mathrm{~g}$ & $83 f$ & $86.5 \mathrm{e}$ & $527 f$ \\
\hline 45 & 0 & 22 & $6690 \mathrm{~h}$ & $86 \mathrm{fg}$ & 80.6gf & $559 \mathrm{~g}$ \\
\hline 90 & 0 & 22 & $7318 \mathrm{i}$ & $92 \mathrm{~g}$ & $78.5 \mathrm{~g}$ & $534 f$ \\
\hline 135 & 0 & 22 & $7472 i$ & $101 \mathrm{~h}$ & $84.6 \mathrm{ef}$ & $522 \mathrm{f}$ \\
\hline 0 & 20 & 22 & $6061 j$ & $85 i$ & $88.5 \mathrm{~h}$ & $544 h$ \\
\hline 45 & 20 & 22 & $6931 \mathrm{k}$ & $92 \mathrm{i}$ & $83.4 h$ & $533 \mathrm{~h}$ \\
\hline 90 & 20 & 22 & 80881 & $108 \mathrm{j}$ & $83.8 \mathrm{~h}$ & $532 \mathrm{~h}$ \\
\hline 135 & 20 & 22 & $8678 \mathrm{~m}$ & $117 \mathrm{k}$ & $83.9 \mathrm{~h}$ & $503 i$ \\
\hline
\end{tabular}

* Values with the same letters were not significantly different at the 0.05 level of confidence.

and $22 \mathrm{~kg} \mathrm{ha}^{-1}$, respectively (Table 3 ). This combination increased the 4-yr average yield by $3716 \mathrm{~kg} \mathrm{ha}^{-1}$ compared to no fertilizer.

The additive effects of $\mathbf{P}$ and $\mathbf{S}$ alone or in combination regressed over increasing $\mathrm{N}$ rates are shown in Fig. 2. These results indicate that the greatest response can be expected from $\mathrm{N}$ and that $\mathrm{P}$ and $\mathrm{S}$ should be considered in addition to $\mathrm{N}$ as part of a fertilization program for increasing forage yields from subirrigated meadows. The initial soil $P$ level showed a need for $\mathrm{P}$ although the $\mathrm{SO}_{4}-\mathrm{S}$ level seemed adequate.

Increased dry matter yield due to $\mathbf{N}$ and $\mathbf{P}$ fertilizer is in general agreement with other studies on subirrigated meadows, although the magnitude of response

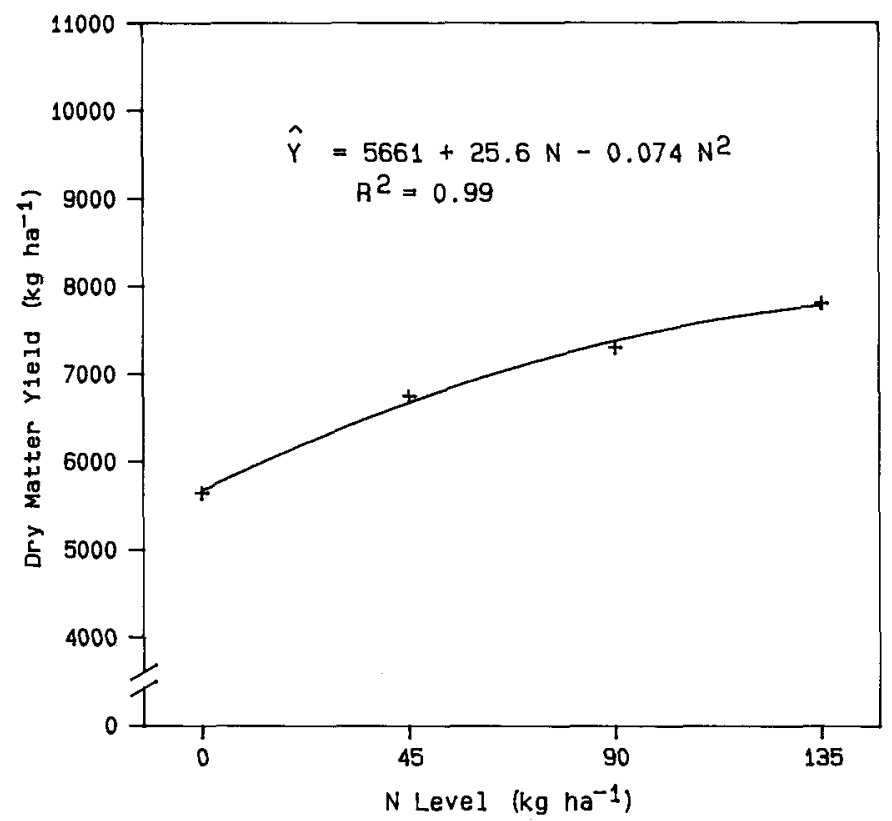

Fig. 1. Average dry matter yields of a subirrigated meadow in response to $\mathrm{N}$ fertilizer (pooled over all $\mathrm{N}, \mathrm{P}$, and $\mathrm{S}$ combinations). Gudmundsen Sandhills Lab., Whitman, NE, 1982 to 1985. and shape of response surfaces may differ (Daigger and Moline, 1977; McConnell and Waller, 1986; Rehm et al., 1973; Rehm et al., 1976). Positive yield responses to $P$ have been reported at all $\mathrm{N}$ rates under conditions of low soil P (Rehm et al., 1973; Rehm et al., 1976). Russell et al. (1965) reported that $\mathrm{N}$ alone had little effect on dry matter production except when combined with $P$. The lack of yield response to $S$, reported by Rehm et al. (1973) was attributed to the high soil organic matter content $\left(60 \mathrm{~g} \mathrm{~kg}^{-1}\right)$. Yield response to $\mathrm{S}$ was significant in our study even though the organic matter content was $111 \mathrm{~g} \mathrm{~kg}^{-1}$ in the top $15 \mathrm{~cm}$ of the soil (Table 1).

\section{Nitrogen Uptake}

Nitrogen uptake increased linearly as $\mathrm{N}$ rates increased from $0 \mathrm{~N}$ to $135 \mathrm{~kg} \mathrm{ha}^{-1}$ (Table 3, Fig. 3). For each kilogram of $\mathrm{N}$ applied, $175 \mathrm{~g} \mathrm{~kg}^{-1}$ of $\mathrm{N}$ was accounted for in the forage. The application of $P$ and $S$ also significantly influenced $\mathrm{N}$ uptake, but there were no interaction effects among fertilizer elements (Table 2). Nitrogen uptake values increased as $\mathrm{N}$ rates were increased from 0 to $135 \mathrm{~kg} \mathrm{ha}^{-1}$ and were highest when $\mathrm{N}$ was applied in combination with $\mathrm{P}$ and $\mathrm{S}$ (Table 3 ). The additive effect of N, P, and S on N uptake was apparent. Nitrogen uptake averaged over all $\mathrm{N}$ rates was increased by 9,8 , and $18 \mathrm{~kg} \mathrm{ha}^{-1}$ when $\mathrm{P}, \mathrm{S}$, or $\mathrm{P}$ $+\mathrm{S}$ were applied, respectively (Table 3 ).

\section{Forage Nitrogen Use Efficiency}

The efficiency of $\mathrm{N}$ use decreased as $\mathrm{N}$ rates were increased. Forage $\mathrm{N}$ use efficiencies (averaged over $\mathrm{P}$ and S) were 40,26 , and $21 \mathrm{~kg} \mathrm{~kg}^{-1} \mathrm{~N}$ for $\mathrm{N}$ rates of 45,90 , and $135 \mathrm{~kg} \mathrm{ha}^{-1}$, respectively (Table 4). The highest yield returns in relation to $\mathrm{N}$ applied were at the lowest $\mathrm{N}$ rates. At a given $\mathrm{N}$ rate, $\mathrm{N}$ use efficiency

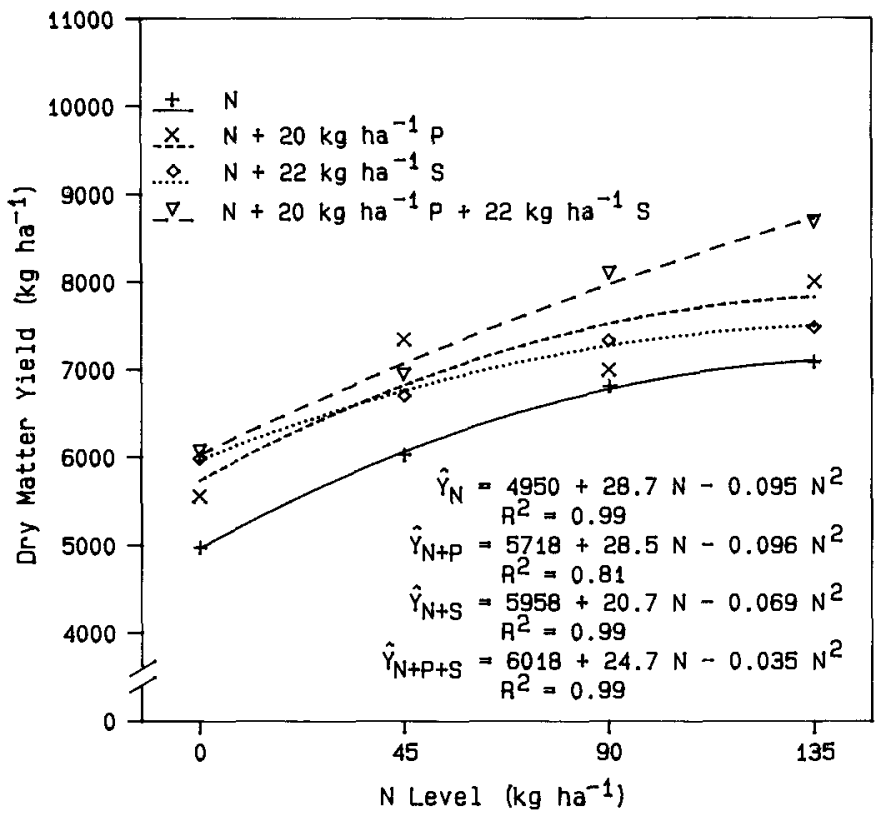

Fig. 2. Average dry matter yields of a subirrigated meadow in response to $\mathbf{N}$ fertilizer alone and with $\mathrm{P}, \mathrm{S}$, and $\mathrm{P}+\mathrm{S}$. Gudmundsen Sandhills Lab., Whitman, NE, 1982 to 1985. 


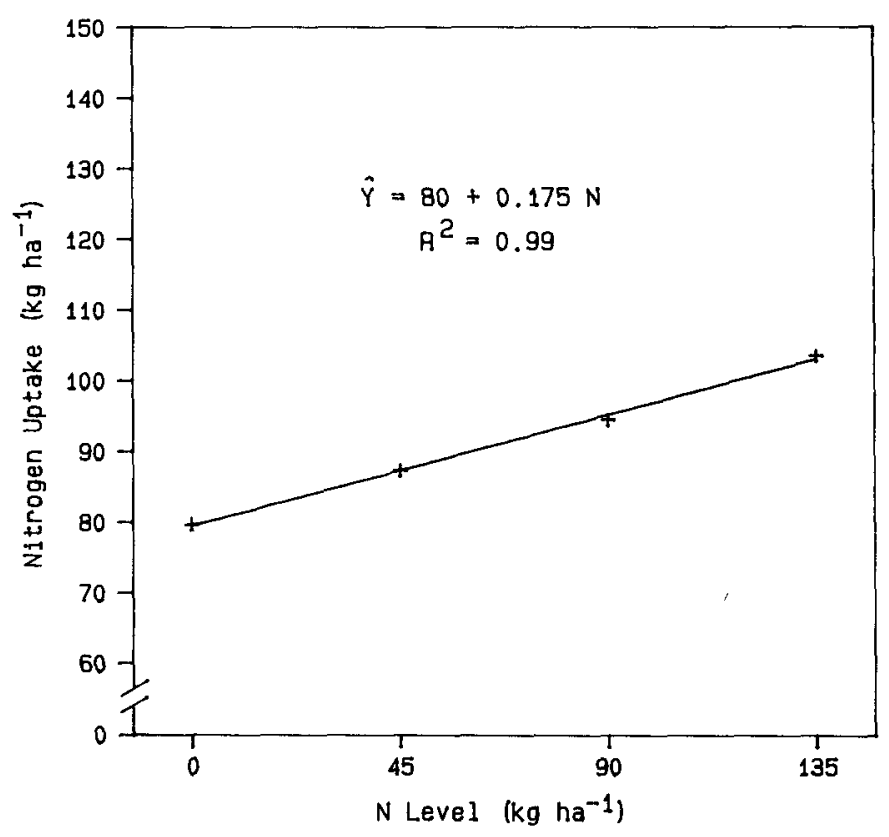

Fig. 3. Average $\mathrm{N}$ uptake from a subirrigated meadow in response to $\mathbf{N}$ fertilizer rates (pooled over all $\mathbf{N}, \mathbf{P}$, and $\mathbf{S}$ combinations). Gudmundsen Sandhills Lab., Whitman, NE, 1982 to 1985.

increased when $\mathbf{P}$ and $\mathbf{S}$ were applied alone or in combination compared to the check treatment (Table 4). The effect averaged across $\mathrm{N}$ rates was also significant. The effects of $\mathrm{N}$ fertilization on the $\mathrm{N}$-use efficiency values were similar to studies in other locations, but the magnitude of the response varied. Gomm (1979) working with native meadows in Oregon reported $\mathrm{N}$ efficiency values from 9 to $11 \mathrm{~kg} \mathrm{~kg}^{-1} \mathrm{~N}$ with fertilizer $\mathrm{N}$ rates of $90 \mathrm{~kg} \mathrm{ha}^{-1}$. At the same $\mathrm{N}$ rate, Ludwick (1979) working on native meadows at three different locations in the northern Rocky Mountains, reported $\mathrm{N}$ efficiencies of $5.8,6.1$, and $8.2 \mathrm{~kg}$ of hay $\mathrm{kg}^{-1} \mathrm{~N}$. These values were all lower than those obtained in the present study at the same $\mathrm{N}$ rate. Taylor et al. (1985) reported forage $\mathrm{N}$ use efficiencies of 13 and $21 \mathrm{~kg} \mathrm{~kg}^{-1}$ $\mathrm{N}$ for $\mathrm{N}$ fertilizer rates of 90 and $135 \mathrm{~kg} \mathrm{ha}^{-1}$, respectively. These values are more comparable to the values of this study (Table 4).

\section{Forage Quality}

\section{Protein}

Crude protein concentration of the forage was reduced by the application of $\mathrm{N}$ fertilizer, but was not

Table 4. Average forage $\mathbf{N}$ use efficiency for subirrigated meadow hay as influenced by fertilization with $N, P$, and $S$ at the Gudmundsen Sandhills Lab., Whitman, NE, 1982 to 1985.

\begin{tabular}{|c|c|c|c|c|c|}
\hline \multirow[b]{2}{*}{$\mathbf{P}$} & \multirow[b]{2}{*}{$\mathbf{S}$} & \multicolumn{3}{|c|}{$\mathrm{N}\left(\mathrm{kg} \mathrm{ha}^{-1}\right)$} & \\
\hline & & 45 & 90 & 135 & \\
\hline \multicolumn{2}{|c|}{$-\mathrm{kg} \mathrm{ha}^{-1}$} & \multicolumn{3}{|c|}{$-\mathrm{N}$ efficiency $\left(\mathrm{kg}\right.$ forage $\left.\mathrm{kg}^{-1} \mathrm{~N}\right)-$} & Avg. \\
\hline $\begin{array}{r}0 \\
0 \\
20 \\
20\end{array}$ & $\begin{array}{r}0 \\
22 \\
0 \\
22\end{array}$ & $\begin{array}{l}23 a^{*} \\
38 a b \\
53 b \\
44 b \\
40 a\end{array}$ & $\begin{array}{l}20 a \\
26 a \\
22 a \\
35 b \\
26 b\end{array}$ & $\begin{array}{l}16 \mathrm{a} \\
19 \mathrm{a} \\
22 \mathrm{ab} \\
28 \mathrm{~b} \\
21 \mathrm{c}\end{array}$ & $\begin{array}{l}20 \mathrm{a} \\
33 \mathrm{bc} \\
28 \mathrm{~b} \\
35 \mathrm{c}\end{array}$ \\
\hline
\end{tabular}

* Values within columns with the same letters were not significantly different at the 0.05 level of confidence (Ryan-Einot-Gabriel-Welsch multiple $F$ test, SAS Institute, Inc., 1985). Note: statistical designation for average values are independent from columns.

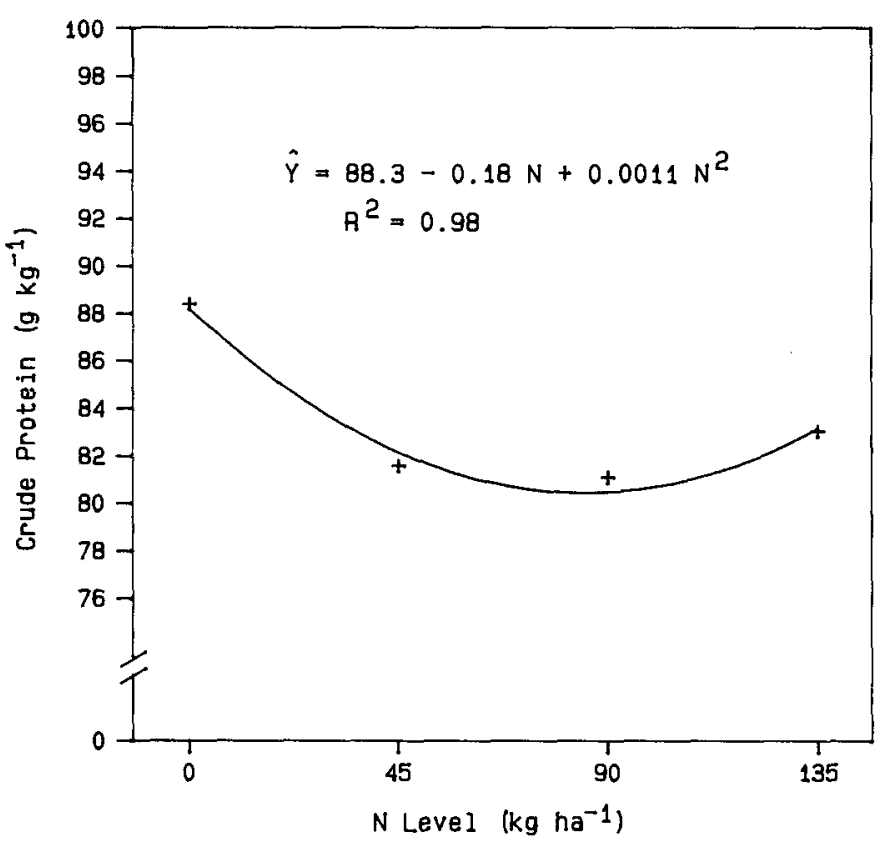

Fig. 4. Average $\mathrm{CP}$ of a subirrigated meadow in response to $\mathrm{N}$ fertilizer (pooled over all N, P, and S combinations). Gudmundsen Sandhills Lab., Whitman, NE, 1982 to 1985.

significantly affected by the application of P or S (Table 2 and 3). There were no significant interactions among any of the applied elements (Table 2). Reductions in $\mathrm{CP}$ concentrations were consistently associated with the first increment of $\mathrm{N}$ applied ( 0 vs. $45 \mathrm{~kg} \mathrm{ha}^{-1}$ ), with little change related to increasing $\mathrm{N}$ rates (Table 3, Fig. 4).

The maximum reduction in $\mathrm{CP}$ was less than $10 \mathrm{~g}$ $\mathrm{kg}^{-1}$ for any mean comparison, and ranged from 1.9 to $9.2 \mathrm{~g} \mathrm{~kg}^{-1}$ (Table 4). Although the reduction in protein content was small, it is a negative response that must be considered in conjunction with the positive yield response. Brouse and Burzlaff (1968) reported a similar response to fertilization with $\mathrm{N}$ alone. In their study, each incremental increase in $\mathrm{N}$ rates from 0 to 45 and $90 \mathrm{~kg} \mathrm{ha}^{-1}$ decreased CP content by $10 \mathrm{~g} \mathrm{~kg}^{-1}$. When rates were increased from 90 to $180 \mathrm{~kg} \mathrm{ha}^{-1}$, the CP content increased by $70 \mathrm{~g} \mathrm{~kg}^{-1}$. The $180 \mathrm{~kg}$ rate was higher than the rates in our study. Similarly, Wilhite et al. (1955) showed a tendency for decreased protein content with $\mathrm{N}$ fertilizer rates below $180 \mathrm{~kg} \mathrm{ha}^{-1}$ and an increase in protein content at higher $\mathrm{N}$ rates.

The protein content of two introduced species, intermediate wheatgrass [Agropyron intermedium (Host) Beauv.] and creeping foxtail (Alopecurus arundinaceus Poir.), on subirrigated mountain meadows in Wyoming increased as $\mathrm{N}$ fertilization rates increased (Hart et al., 1980). Other studies summarized by Hart et al. (1980) involving native species on subirrigated sites, indicated that $\mathrm{N}$ fertilization reduced $\mathrm{CP}$ content, or caused no change, depending on location. Brouse and Burzlaff (1968) found that fertilization of mixed grasslegume meadows in Nebraska with $\mathrm{N}$ and $\mathrm{P}$ resulted in hay $\mathrm{CP}$ contents that were associated with fertilizer induced changes in botanical composition. Nitrogen stimulated grass growth and suppressed legume production, whereas $P$ increased the legume component. Since legumes were higher in CP than grasses, these shifts in composition were reflected in CP content. In 


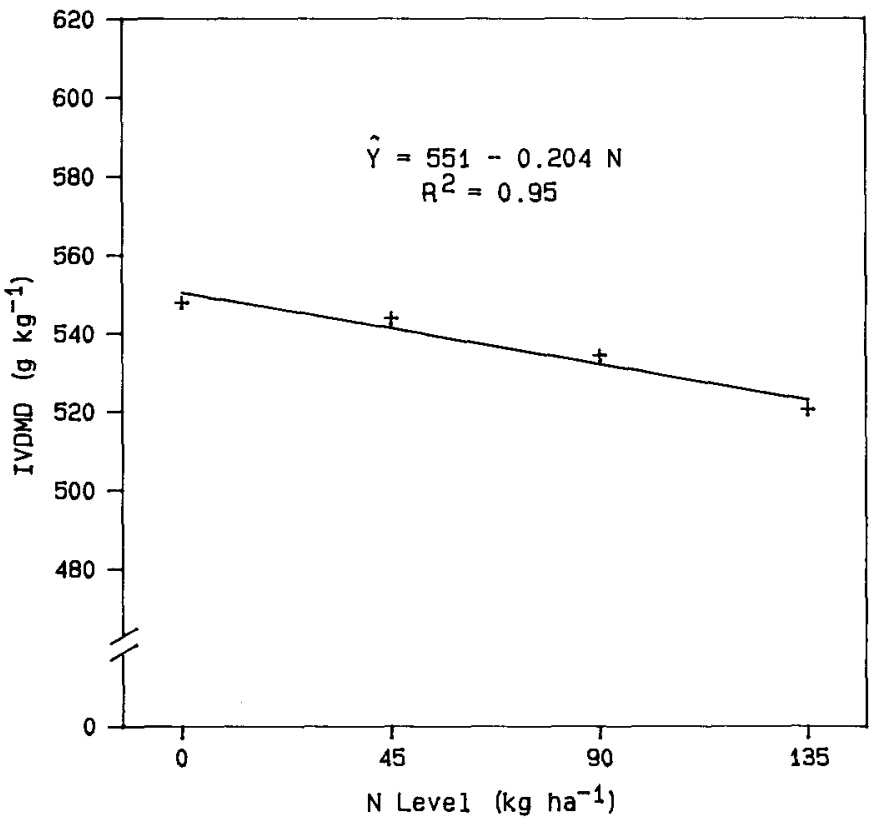

Fig. 5. Average IVDMD of a subirrigated meadow in response to $\mathbf{N}$ fertilizer (pooled over all $\mathbf{N}, \mathbf{P}$, and $\mathbf{S}$ combinations). Gudmundsen Sandhills Lab., Whitman, NE, 1982 to 1985.

our study, legumes were only a minor component of the vegetation and did not show a response to $P$.

\section{Digestibility}

In vitro dry matter digestibility decreased as $\mathrm{N}$ rates were increased, but there were no significant differences in IVDMD as a result of $\mathbf{P}$ and $\mathbf{S}$ applications (Table 2). There were no interactions among any fertilizer combinations (Table 2). The highest IVDMD percentages were those associated with $\mathrm{O}-\mathrm{N}$ rates $(\mathrm{Ta}-$ ble 3). Digestibility was reduced by $26 \mathrm{~g} \mathrm{~kg}^{-1}$ when 45 $\mathrm{kg} \mathrm{ha}^{-1}$ of $\mathrm{N}$ (O-P, O-S) was applied compared to O$\mathrm{N}$. Additional increases in $\mathrm{N}$ rates $(\mathrm{O}-\mathrm{P}, \mathrm{O}-\mathrm{S})$ did not cause a significant change in IVDMD (Table 3 ). The regression of IVDMD means over $\mathrm{N}$ rates (pooled over $P$ and $S$ rates) showed a negative, linear response (Fig. 5). These analyses indicate that a reduction of approximately $9 \mathrm{~g} \mathrm{~kg}^{-1}$ IVDMD could be expected for each $45 \mathrm{~kg} \mathrm{ha}^{-1}$ of $\mathrm{N}$ applied when $\mathrm{N}$ fertilization rates ranged from 0 to $135 \mathrm{~kg} \mathrm{ha}^{-1}$. In contrast, Daigger and Burzlaff (1972) indicated that fertilization of subirrigated meadows with $\mathrm{N}, \mathrm{P}$, and $\mathrm{K}$ at four different locations did not influence IVDMD of forage from subirrigated meadows in Nebraska. In Wyoming, Waggoner et al. (1979) analyzed 30 hays from five locations and indicated that fertilization appeared to increase digestibility of protein hemicellulose, cellulose, and crude fiber from all hays examined, but the differences were not statistically different. It is apparent that the effect of fertilization on forage digestibility is highly variable and that other factors such as the stage of plant maturity may have more influence.

The reduction in IVDMD caused by $\mathrm{N}$ fertilization in our study must be evaluated in conjunction with positive yield responses discussed previously. For example, the average yield increase for the first $45 \mathrm{~kg}$ $\mathrm{ha}^{-1}$ of $\mathrm{N}$ (with no P or S) was $1050 \mathrm{~kg} \mathrm{ha}^{-1}$ (Table 3). The corresponding reduction in IVDMD was $26 \mathrm{~g} \mathrm{~kg}^{-1}$ at the same $\mathrm{N}$ rate, which was minimal compared to the yield increase. This relationship of increased yield and decreased digestibility for the first increment of $\mathrm{N}$ was consistent over all $\mathrm{P}$ and $\mathrm{S}$ fertilizer combinations (Table 3 ).

The two forage quality parameters measured in this study, CP and IVDMD, were both impacted negatively by fertilizer $N$. Although the magnitude of the responses were relatively small, forage quality is a factor that must be considered when making fertilizer recommendation for subirrigated meadows.

Although we lack supporting data, it is hypothesized that $\mathrm{N}$ fertilization lowered $\mathrm{CP}$ and IVDMD values by stimulating culm elongation, thus reducing the leaf to stem ratio. Since it is commonly accepted that protein content and digestibility are higher for leaves than stems, values obtained from total plant analysis for $\mathrm{CP}$ content and IVDMD would be altered by any change in this ratio. Unpublished data from a study now in progress supports this explanation.

\section{SUMMARY}

Nitrogen, $P$, and $S$ fertilizer increased dry matter yields of hay from a subirrigated meadow in the Nebraska Sandhills. There were no interaction effects among fertilizers on yield. Since yield responses to N, $P$, and $S$ were additive, the highest yields were obtained when nutrients were applied in combination. Yield responses to fertilization by year were similar with no change in trends in fertilizer response over time. These data support the practice of fertilizing subirrigated meadows in the Nebraska Sandhills with N, $P$, and $S$. The yield responses were adequate to warrant its consideration as an economically feasible practice.

Nitrogen uptake increased as the rate of $\mathrm{N}$ fertilizer increased, but only $17.5 \%$ of the applied $\mathrm{N}$ was accounted for in the forage. The efficiency of $\mathrm{N}$ use decreased as $\mathrm{N}$ fertilization rates increased. Protein content and IVDMD of the forage were reduced by the application of $\mathrm{N}$ fertilizer, but they were not affected by $\mathrm{P}$ and $\mathrm{S}$. The magnitude of these forage quality responses were small. Crude protein was reduced by less than $1 \%$ for any $P, S$, or $P+S$ fertilizer combination for all $\mathrm{N}$ rates and IVDMD by about $0.9 \%$ for each increment ( $45 \mathrm{~kg} \mathrm{ha}^{-1}$ ) of $\mathrm{N}$ applied.

Decreases in forage quality caused by $\mathrm{N}$ fertilization should be considered in relation to the increased dry matter yields when evaluating the feasibility of fertilizing subirrigated meadows. The pronounced yield increases from fertilization more than compensate for the minor reductions in forage quality. For example, a yield increase of $63 \%$ resulted from the application of 90,20 , and $22 \mathrm{~kg} \mathrm{ha}^{-1}$ of $\mathrm{N}, \mathrm{P}$, and S, respectively compared to a reduction in CP and IVDMD of 0.68 and $2.9 \%$, respectively. However, the importance of maximizing forage quality for the livestock producer should not be overlooked. Harvesting at a less mature stage of plant development should be investigated as a means of improving quality while maintaining yield on subirrigated meadows.

\section{REFERENCES}

Association of Official Analytical Chemists. 1975. Official methods of analysis (12th ed.). AOAC, Washington. DC.

Brouse, E.M., and D.F. Burzlaff. 1968. Fertilizers and legumes on subirrigated meadows. Univ. of Nebraska Agric. Exp. Stn. Bull. 501.

Daigger, L.A., and D.F. Burzlaff. 1972. Fertilization of subirrigated 
meadows in western Nebraska. Univ. of Nebraska Agric. Exp. Stn. Sci. Bull. 521.

Daigger, L.A., and W.J. Moline. 1977. Sources, rates and frequencies of N application in subirrigated hay meadows. Agron. J. 69:644647.

Ehlers, P., G. Viehmeyer, R. Ramig, and E.M. Brouse. 1952. Fertilization and improvement of native subirrigated meadows in Nebraska. Univ. of Nebraska Agric. Exp. Stn. Cir. 92.

Gomm, F.B. 1979. Management alternatives for native meadowlands. Oregon State Univ. Agric. Exp. Stn. and USDA Agric. Res. Spec. Rep. 532, Corvallis, OR.

Great Plains Flora Association. 1986. Flora of the Great Plains. Univ. Press of Kansas. Lawrence, KS.

Hart, R.H., H.R. Haise, D.D. Walker, and R.D. Lewis. 1980. Mountain meadow management: 12 years of variety, fertilization, irrigation and renovation research. USDA-SEA Publ. Agric. Res. Results, West. Series, no. 16, Oakland, CA.

Ludwick, A.E. 1979. Meadow hay production as influenced by nitrogen and phosphorus fertilization. p. 71-80. In R.H. Delaney and J. Borrelli (ed.) Management of intermountain meadows. Symp. Proc. RJ 141, Jackson, WY. 7-9 June 1979. Univ. of Wyoming, Laramie and Colorado State Univ., Ft. Collins, CO.

Martin, G.C., and R.J. Barnes. 1980. Prediction of energy digestibility of forages with in vitro rumen fermentation and fungal enzyme systems. p. 61-71. In W.D. Pigden et al. (ed.) Standardization of analytical methodology for feeds. Int. Devel. Res. Cent., Ottawa, Can.
McConnell, S.G., and S.S. Waller. 1986. Subirrigated meadow response to application of nitrogen, phosphorus and atrazine. Agron. J. 78:629-632.

Rehm, G.W., W.J. Moline, R.C. Sorensen, and D.F. Burzlaff. 1973. Response of subirrigated hay meadows to the application of nitrogen, phosphorus and sulfur. Agron. J. 65:665-668.

Rehm, G.W., R.C. Sorensen, and W.J. Moline. 1976. Time and rate of fertilizer application for seeded warm-season and bluegrass pastures. I. Yield and botanical composition. Agron. J. 68:759-764.

Russell, J.S., E.M. Brouse, H.F. Rhoades, and D.F. Burzlaff. 1965. Response of sub-irrigated meadow vegetation to application of nitrogen and phosphorus fertilizer. J. Range Manage. 18:242-247.

SAS Institute, Inc. 1985. SAS user's guide: Statistics, 5th ed. SAS Institute, Inc., Cary, NC.

Snedecor, G.W., and W.G. Cochran. 1968. Statistical methods. 6th ed. Iowa State Univ. Press, Ames, IA.

Taylor, D.T., W.J. Seamands, D.J. Menkhaus, J.J. Jacobs, and R.H. Delaney. 1985. An economic analysis of $N$ fertilization of intermountain hay meadows. Agron. J. 77:17-20.

Waggoner, J.W., H.D. Radloff, and W.L. Eberhart. 1979. Nutrient content of forages harvested in Wyoming. p. 115-131. In R.H. Delaney and J. Borrelli (ed.) Management of intermountain meadows. Symp. Proc. RJ 141, Jackson, WY. 7-9 June 1979. Univ. of Wyoming, Laramie and Colorado State Univ., Ft. Collins, CO.

Wilhite, F.M., H.K. Rouse, and D.E. Miller. 1955. High altitude meadows in Colorado: III. The effect of nitrogen fertilization on crude protein production. Agron. J. 117-121. 